\title{
Rancang Bangun Pencarian Rumah Sakit, Puskesmas dan Dokter Praktek Terdekat di Wilayah Manado Berbasis Android
}

\author{
Astrid A. A. Makiolor ${ }^{1}$, Alicia A. E. Sinsuw ${ }^{2}$, Xaverius B. N. Najoan ${ }^{3}$ \\ Teknik Informatika Universitas Sam Ratulangi. Manado, Jl. Kampus Unsrat Bahu, Manado 95115 \\ astridmakiolor@gmail.com¹, alicia.sinsuw@unsrat.ac.id ${ }^{2}$,xnajoan@unsrat.ac.id ${ }^{3}$
}

\begin{abstract}
Abstrak - Skripsi ini berisi tentang Aplikasi Pencarian Rumah Sakit, Puskesmas dan Dokter Praktek terdekat di wilayah Manado Berbasis Android, dengan menggunakan aplikasi Android Studio yaitu aplikasi untuk pembuatan aplikasi android. Aplikasi ini bertujuan untuk mempermudah masyarakat dalam mencari Rumah Sakit, Puskesmas dan dokter praktek terdekat saat dalam keadaan panik dan membutuhkan pertolongan pertama terutam bagi masyarakat dari luar Manado yang datang berkunjung di Kota Manado atau yang datang berlibur di kota Manado. Metode yang digunakan dalam aplikasi android ini adalah metode prototype yang merupakan sebuah javascript framework yang di buat untuk lebih memudahkan proses dalam membangun aplikasi. Metode Prototype merupakan metode pengembangan system dimana hasil analisa bisa langsung di terapkan kedalam sebuah model tanpa harus menunggu sebuah hasil analisa selesai.
\end{abstract}

Kata kunci: framework, javascript, prototype.

\section{PENDAHULUAN}

Pada zaman sekarang ini Teknologi berkembang sangat pesat. Hal ini menjadikan komunikasi sangat beragam dan bisa memudahkan kita dalam mengakses dan juga berkomunikasi dengan siapa saja dan dimana saja. Teknologi terutama di bagian komunikasi seluler yang pada saat ini dalam bentuk gadget (smartphone) sudah bisa dimiliki oleh setiap lapisan masyarakat karena harganya yang relative murah dan juga mudah didapatkan. Seiring berkembangnya smartphone yang sudah dilengkapi dengan system operasi Android menambah kegunaannya dengan tampilan yang menarik untuk digunakan. Pada saat ini hampir semua handphone Android sudah di lengkapi dengan fitur Global Positioning System atau yang disingkat GPS. Dimana dengan adanya fitur GPS ini lebih memudahkan masyarakat dalam mencari dan menemukan lokasi yang ingin dituju.

Kota Manado dalam upaya mewujudkan visi Manado Kota Cerdas pada tahun 2021, pemerintah dan masyarakat Kota Manado akan menyelenggarakn berbagai program terkait untuk pengembangan dan pengelolaan Kota dengan pemanfaatan Teknologi Informasi dan Komunikasi (TIK) dalam rangka memaksimalkan pelayanan kepada masyarakat serta mendukung pembangunan Kota yang berkelanjutaan. Dalam melakukan aktifitas sehari-hari kesehatan merupakan hal terpenting dalam kehidupan manusia. Dalam undang-undang Nomor 36 Tahun 2009 pasal 1, 1 tentang kesehatan, yaitu kesehatan merupakan Kebutuhan dasar dan hak asasi manusia yang dijamin oleh Negara. Kesehatan didefinisikam sebagai keadaan sehat, baik secara fisik, mental dan spiritual maupun social yang memungkinkan setiap orang untuk hidup produktif secara social dan ekonomis.

Setiap orang pasti ingin keluarga dan temanteman dan orang terdekatnya selalu sehat, dan untuk mendapatkan kesehatan itu, kita harus sesering mungkin melakukan pemeriksaan atau chekup kesehatan di Rumah Sakit atau Puskesmas, bahkan kita juga bisa memeriksa kesehatan diri kita kepada dokter spesialis penyakit yang membuka tempat praktek di berbagai Klinik. Saat dalam keadaan darurat dan panik, kita seringkali mengalami kesulitan mencari informasi dimana letak fasilitas kesehatan yang ada disekitar kita.

Oleh karena itu atas dasar permasalahan dan fakta diatas maka untuk mengatasi hal-hal tersebut penulis berinisiatif untuk membuat aplikasi dalam mempermudah masyarakat dalam mencari Rumah Sakit, Puskesmas dan juga Klinik di Kota Manado serta membantu dalam salah satu program pemerintah dalam upaya mewujudkan visi Manado Kota Cerdas 2021. Maka di buatlah aplikasi Pencarian Rumah Sakit, Puskesmas dan juga Dokter Praktek berbasis mobile dengan platform Android. Aplikasi ini diakses hanya pada handphone yang sudah memiliki fasilitas GPS. Android menjadi pertimbangan dalam mengembangkan aplikasi ini 
karena perangkat ini banyak digunakan masyarakat karena kemudahan menggunakannya. Aplikasi ini nantinya akan memberikan Informasi dan letak atau lokasi Rumah Sakit dan Puskesmas dan juga tempat Dokter Praktek di Klinik, Seperti Lokasi, alamat, dan juga nomor telepon yang tersedia pada Rumah Sakit dan Puskesmas dan tempat praktek dokter tersebut. Tidak hanya itu aplikasi ini juga dapat menampilkan peta, yang akan membantu masyarakat dengan rute menuju lokasi Rumah Sakit, Puskesmas dan Dokter Praktek terdekat yang akan di tuju.

\section{LANDASAN TEORI}

\section{A. Sistem Informasi Geografis}

Sistem Informasi Geografis adalah system yang terdiri dari perangkat keras, perangkat lunak, data, manusia (brainware), organisasi dan lembaga yang digunakan untuk mengumpulkan, menyimpan, menganalisis, dan menyebarkan informasi-informasi mengenai daerah-daerah dipermukaan bumi. Sistem Informasi Geografis mempunyai kemampuan untuk menghubungkan berbagai data pada suatu titik tertentu dibumi, menggabungkannya, menganalisa, dan akhirnya memetakan hasilnya. Data yang diolah pada SIG adalah data spasial yaitu sebuah data yang berorientasi geografis dan merupakan lokasi yang memiliki sistem koordinat tertentu, sebagai dasar refrensinya. Sehinggah aplikasi SIG dapat menjawab beberapa pertanyaan seperti lokasi, kondisi, tren, pola dan pemodelan. Kemampuan inilah yang membedakan SIG dengan system informasi lainnya. (Chrisman, 1997)

\section{B. Location Based Service (LBS)}

Layanan Berbasis Lokasi adalah layanan informasi yang dapat diakses melalui mobile divice dengan menggunakan mobile network, yang dilengkapi kemampuan untuk memanfaatkan lokasi dari mobile device tersebut. LBS memberikan kemungkinan komunikasi dan interaksi dua arah.

Oleh karena itu pengguna memberi tahu penyedia layanan untuk mendapatkan informasi yang dia butuhkan, dengan refrensi posisi pengguna tersebut. Layanan berbasis lokasi dapat digambarkan sebagai suatu layanan yang berada pada pertemuan tiga teknologi yaitu: Geographic Information System, Internet Service, dan Mobile Device, hal ini dapat dilihat pada gambar LBS adalah pertemuan dari 3 Teknologi. (Safaat N, 2013).

\section{C. $\quad$ GPS (Global Positioning System)}

Global Positioning System atau sering disebut GPS adalah sistem untuk menentukan letak di permukaan bumi dengan bantuan penyelarasan (synchronization) sinyal satelit. Sistem ini menggunakan 24 satelit yang mengirimkan sinyal gelombang mikro ke bumi. GPS pertama kali dikembangkan oleh Amerika Serikat dengan tujuan untuk membantu pasukan Amerika Serikat dalam menghadapi perang Vietnam.Fungsi utama dari GPS adalah untuk memberikan informasi tentang posisi, kecepatan dan waktu secara akurat. Akurasi atau ketepatan perlu mendapat perhatian bagi penentuan koordinat sebuah titik atau lokasi. Koordinat posisi ini akan selalu mempunyai 'faktor kesalahan', yang lebih dikenal dengan 'tingkat akurasi'. Misalnya alat tersebut menunjukan sebuah titik koordinat dengan akurasi 3 meter, artinya posisi sebenarnya bisa berada dimana saja dalam radius 3 meter dari titik lokasi. Tingkat akurasi GPS sangat dipengaruhi oleh factor sekeliling yang mengurangi kekuatan sinyal satelit. Ada banyak hal yang dapat mengurangi kekuatan sinyal satelit, diantaranya :

1. Kondisi geografis, selama kita masih dapat melihat langit yang cukup luas, kekuatan sinyal semakin baik pula

2. Hutan. Makin lebat hutannya, maka makib berkurang sinyal yang didapat.

3. Air. Saat menyelam ke dalam air, GPS tidak akan berfungsi.

4. Gedung-gedung. Tidak hanya didalam gedung, berada diantara gedung tinggi juga dapat mengganggu kekuatan sinyal.

GPS adalah singkatan dari Global Positioning System, yang merupakan sistem navigasi dengan menggunakan teknologi satelit yang dapat menerima sinyal dari satelit. . Sistem ini menggunakan 24 satelit yang mengirimkan sinyal gelombang mikro ke bumi. Dengan GPS atau Global Positioning System lokasi tempat anda berada bisa diketahui dengan memanfaatkan signal satellite teknologi GPS banyak digunakan untuk menunjukan jalan sering juga disebut sebagai teknologi anti sesat, fungsi GPS biasanyaakan diaktifkan secara otomatis oleh program navigasi namun terkadang anda harus mengaktifkan dan mematikanya secara manual.penggunaan GPS akan menggunakan daya listrik. ( Ciu Bun seng, 2011). GPS memungkinkan develover mengakses lokasi pengguna kapan pun. Anda bisa mentrek lokasi ketika xpengguna mengubah lokasi, anda bisa menentukan lokasi ponsel kemudian mengakses web untuk menentukan lokasi publik yang dekat dengan pengguna (Kasman, 2013 ).

\section{Android}

Android adalah sistem operasi untuk telepon seluler berbasis Linux sebagai kernelnya. Awalnya perusahaan search engine terbesar saat ini, yaitu Google Inc. membeli Android Inc. yang merupakan pendatang baru yang membuat peranti lunak untuk 
ponsel. Android Inc. didirikan oleh Andy Rubin, Rich Milner, Nick Sears, dan Chris White pada tahun 2003. Untuk mengembangkan Android lebih lanjut dibentuklah Open Handset Alliance konsosrsium dari 34 perusahaan hardware, software dan telekomunikasi, termasuk Google, HTC, Intel, Motorola, Qualqomm, Tmobile dan Nividia. Tanggal 5 November 2007 merupakan perilisan perdana Android dan sekaligus menjadi moment dimana Google dan Open Handset Alliance menyatakan mendukung pengembangan standar terbuka pada perangkat seluler. Android memiliki dua distributor, yaitu Google Mail Service dan Open Handset Distributor (OHD). Saat ini Android menjadi pesaing utama dari produk smartphone lainnya seperti Apple dan Blackberry karena Android memiliki beberapa kelebihan daripada smartphone lain, yaitu

a) Android bersifat Open Source yang artinya pengembang (Developer Android) bebas untuk mengembangkan aplikasi pada platform ini.

b) Lengkap. Android menyediakan tools untuk membangaun software yang sangat lengkap dibanding dengan platform lain.

c) Bebas (Free Platform). Android adalah platform mobile yang tidak memiliki batasan dalam mengembangkan aplikasinya. Tidak ada lisensi dalam mengembangkan aplikasi Android.

Android adalah sebuah sistem operasi untuk perangkat mobile berbasis linux yang mencakup sistem operasi, middleware dan aplikasi. Android menyediakan platform terbuka bagi para pengembang untuk menciptakan aplikasi mereka. Awalnya Google Inc. membeli Android Inc. yang merupakan pendatang baru yang membuat piranti lunak ponsel atau smartphone. ( Nazruddin Safaat, 2013)

Android SDK (Software Development Kit)

Android SDK (Software Development Kit) adalah tool dan alat bantu API (Aplication Programing Interfaces) yang diperlukan untuk mengembangkan aplikasi berbasis Android menggunakan bahasa pemograman Java. SDK sering juga disebut sebagai software emulator yang berguna untuk mensimulasikan OS Android pada PC.(Kasman, 2014)

\section{E. Android Studio}

Android Studio adalah sebuah IDE yang bisa digunakan untuk pengembangan aplikasi Android, dan dikembangkan oleh google. Android Studio merupakan pengembangan dari Eclipse IDE, dan dibuat berdasarkan IDE Java populer, yaitu IntelliJ IDEA. Android Studio Di rencanakan untuk menggantikan Eclipse ke depannya sebagai IDE resmi untuk pengembangan aplikasi Android.

Sebagai Pengembangan dari Eclipse Android Studio mempunyai banyak fitur-fitur baru dibandingkan dengan Eclipse IDE. Berbeda dengan Eclipse yang menggunakan ADT, Android Studio Menggunakan gradle sebagai build environment. Fitur-fitur lainnya adalah sebagai berikut:

1) Menggunakan Gradle-based build system yang fleksibel.

2) Bisa mem-build multiple APK.

3) Template support untuk Google Service dan berbagai macam tipe perangkat.

4) Layout editor yang lebih bagus.

\section{F. Prototype}

Menurut Pressman (2012), dalam melakukan perancangan sistem yang akan dikembangkan dapat menggunakan metode prototipe. Metode ini cocok digunakan untik mengembangkan sebuah perangkat yang akan dikembangkan kembali. Metode ini dimulai dengan pengumpulan kebutuhan pengguna, dalam hal ini pengguna dari perangkat yang dikembangkan. Kemudian membuat sebuah rancangan yang selanjutnya akan dievaluasi kembali sebelum diproduksi secara benar.

Metode prototipe di mulai dari tahap komunikasi. Tim Pengembang perangkat lunak melakukan kebutuhan perangkat lunak yang saat itu diketahui dan untuk menggambarkan area-area dimana definisi lebih jauh untuk iterasi selanjutnya.

Perencanaan iterasi pembuatan prototipe dilakukan secara cepat. Setelah itu dilakukan pemodelan dalam bentuk "Rancangan Cepat". Pembuatan Rancangan cepat berdasarkan pada representasi aspek-aspek perangkat lunak yang akan terlihat oleh para end user (misalnya rancangan pembuka antarmuka pengguna atau format tampilan). Rancangan cepat merupakan dasar untuk memulai kontruksi pembuatan prototipe.

Prototipe kemudian di serahkan pada stakeholder untuk mengevalkuasi prototype yang telah dibuat sebelumnya dan memberikan umpanbalik yang akan digunakan untuk memperbaiki spesifikasi kebutuhan. Iterasi terjadi saat pengembang melakukan perbaikan terhadap prototype tersebut.

Prototipe bukanlah merupakan sesuatu yang lengkap, tetapi sesuatu yang harus dievaluasi dan dimodifikasi kembali. Segala perubahan dapat terjadi pada saat yang sama memungkinkan pengembang untuk lebih memahami kebutuhan pengguna secara lebih baik. 


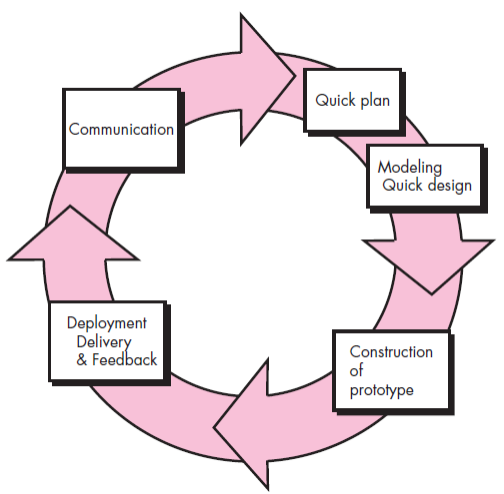

Gambar 1. Metode Prototype

\section{METODOLOGI PENELITIAN}

\section{A. Identifikasi masalah}

Berikut ini adalah identifikasi masalah dari hasil observasi yang dilakukan di Rumah Sakit, Puskesmas dan Klinik di Kota Manado:

1. Bagi masyarakat dari luar Manado yang datang ke Manado, proses dalam menemukan lokasi fasilitas Kesehatan terdekat seperti Rumah Sakit, Puskesmas dan Klinik, masih manual dan membutuhkan waktu yang cukup lama untuk bisa mengetahui dengan pasti lokasi terdekat dari Fasilitas Kesehatan yang ada di Kota Manado.

2. Dalam Situasi darurat, ada kerabat kita yang sakit parah dan harus segera di tangani oleh dokter, untuk dapat mengetahui lokasi suatu Rumah Sakit, Puskesmas dan Klinik terdekat dengan posisi kita, kita harus melalui proses yang panjang. Sementara itu kita harus mementingkan keselamatan utama dari kerabat kita yang sedang sakit.

\section{B. Pengumpulan data}

Berikut ini adalah metode pengumpulan data yang digunakan peneliti dalam penelitian ini:

1. Studi Literatur

Mencari dan Mengumpulkan referensi dari berbagai sumber dan dari buku-buku yang berhubungan dengan masalah pada penelitian ini.

2. Observasi

Observasi dilakukan dengan turun langsung ke Dinas Kesehatan Kota Manado dengan mengumpulkan data berupa jumlah lokasilokasi Fasilitas Kesehatan yang ada di Kota Manado, yaitu Rumah Sakit, Puskesmas dan Klinik.

\section{Metode Pengembangan Aplikasi}

Berikut ini adalah metode pengembangan aplikasi yang di gunakan untuk membangun aplikasi Pencarian Rumah Sakit, Puskesmas dan Klinik terdekat di Kota Manado adalah metode prototipe. Metode prototipe di pilih penulis karena membantu proses pengembangan dan stakeholder untuk memahami apa yang harus dibangun ketika proses yang ada masih manual, dapat mengembangkan system dengan waktu yang singkat.

\section{Tahap Komunikasi Untuk Pengumpulan Data}

Pada Tahap ini dilakukan komunikasi antara pengembang perangkat lunak dengan pengguna untuk mendefinisikan secara keseluruhan untuk perangkat lunak yang dikembangkan, mengidentifikasi spesifikasi kebutuhan apapun yang saat ini diketahui.

\section{Tahap Perencanaan Secara Cepat}

Tahap ini adalah tahap perencanaan secara cepat sesuai dengan hasil dari tahap sebelumnya, dimana akan dilakukan perencanaan tentang tools apa saja yang akan digunakan.

\section{Tahap Pemodelan Perancangan Secara Cepat}

Dalam mendesain aplikasi, analisa dilakukan untuk memahami sifat program yang akan dibangun, cara kerja dari program yang dibangun, dan interface yang di perlukan dari aplikasi dalam waktu yang singkat.

\section{Tahap Pembentukan Prototype}

Pembuatan dan pengujian prototype untuk aplikasi berdasarkan perancangan cepat pada tahap sebelumnya.

\section{Tahap Penyerahan Sistem}

Mendapatkan umpan balik dari pengguna berdasarkan prototype yang dibuat untuk memperjelas kebutuhan perangkat lunak.

\section{HASIL DAN PEMBAHASAN}

\section{A. Tahap Komunikasi}

Pada tahap ini, peneliti melakukan identifikasi spesifikasi kebutuhan yang dibutuhkan dengan cara wawancara langsung pada pengguna, yang nanti akan menggunakan aplikasi ini. Karena sampai saat ini untuk mendapatkan lokasi Fasilitas Kesehatan terdekat dengan posisi pengguna, membutuhkan proses yang panjang, hal ini bisa jadi membahayakan keselamatan seseorang. 


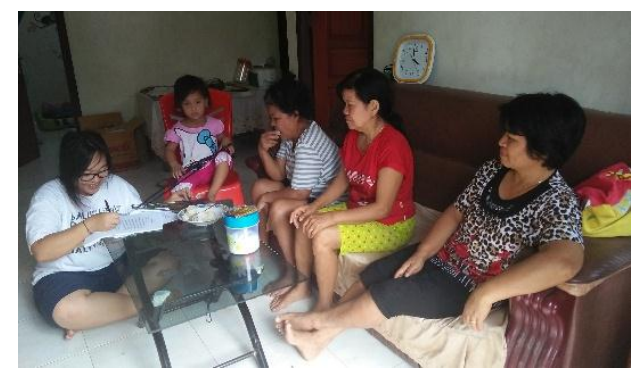

Gambar 2. Wawancara dengan Masyarakat

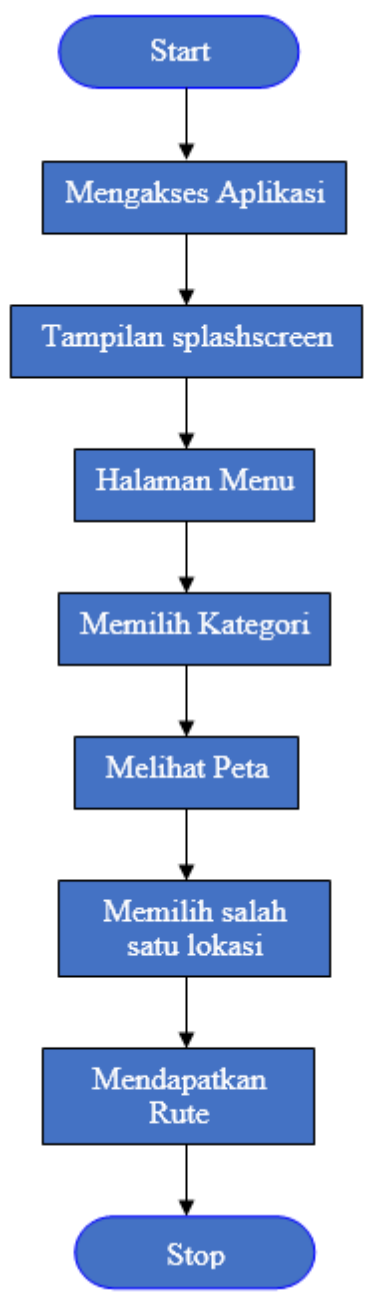

Gambar 3. Proses Bisnis Menggunakan Aplikasi

Pada Gambar 3 menjelaskan proses bisnis saat aplikasi dijalankan, yaitu dimulai saat user mengetahui ada kerabat yang sakit kemudian user mengakses aplikasi faskes manado pada handphone android, kemudian aplikasi menampilkan tampilan splashscreen setelah itu masuk ke halaman menu, kemudian memilih kategori fasilitas kesehatan, setelah itu aplikasi akan menampilkan peta yang berisi marker kategori yang dipilih dan posisi yang terdekat dengan user, aplikasi juga menampilkan popup yang berisi detail Informasi, kemudian aplikasi menampilkan rute.

\section{B. Tahap Perencanaan Secara Cepat}

Pada tahap ini penulis akan mendefinisikan batas waktu yang berhubungan dengan aplikasi yang akan di buat, aplikasi yang dibuat dalam batas waktu yang singkat dengan membuat jadwal penelitian dan menentukan tools apa saja yang akan digunakan. Berikut ini adalah tools yang akan digunakan dalam pembuatan aplikasi ini:

1. Aplikasi ini dibuat di Android Studio 2.2

2. Aplikasi ini menggunakan SDK Manager (Software Development Kit)

\section{Tahap Pemodelan Perancangan Secara Cepat}

Pada tahap ini penulis akan menganalisa kebutuhan-kebutuhan perangkat lunak yang akan dibutuhkan dan mendesain cara kerja dari system yang akan dibuat, interface, dan fitur-fitur yang mendukung.
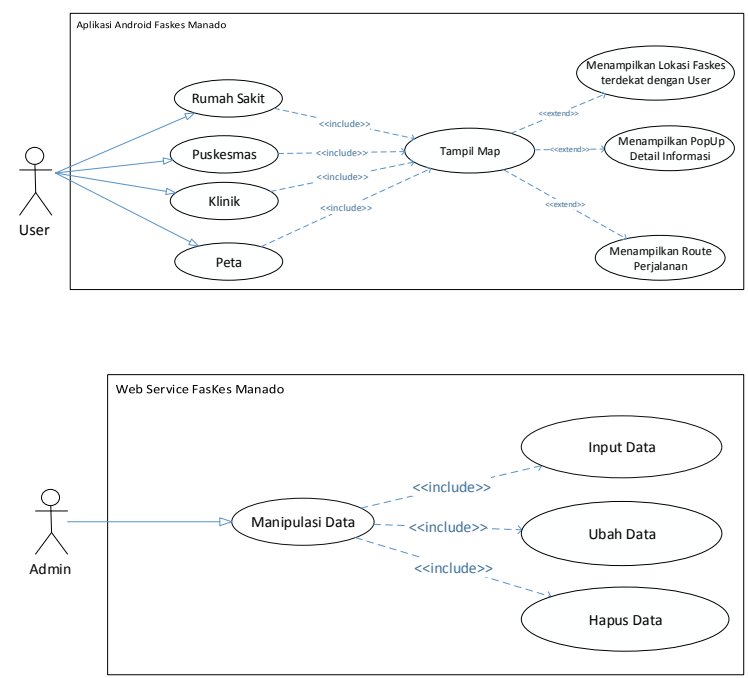

Gambar 4. Use Case Diagram User dan Admin

Berdasarkan Gambar 4 saat User mengakses aplikasi user akan masuk kehalaman menu kemudian memilih kategori fasilitas kesehatan, yaitu Rumah Sakit, Puskesmas dan Klinik, untuk pilihan peta, akan ditunjukkan hasil marker dari semua lokasi. Setelam memilih kategori user akan masuk kehalaman peta yang berisi marker dan info berupa popup. Untuk usecase admin, admin memanipulasi data yang 
berada di web service, yaitu input data, ubah data, dan hapus data.

Class diagram menggambarkan struktur aplikasi dari segi pendefinisian class yang akan dibuat untuk membangun aplikasi. Class memiliki apa yang disebut atribut dan metode atau operasi.

Aplikasi Pencarian rumah Sakit, Puskesmas dan Dokter Praktek Terdekat ini memiliki Class Diagram seperti pada gambar 5 .

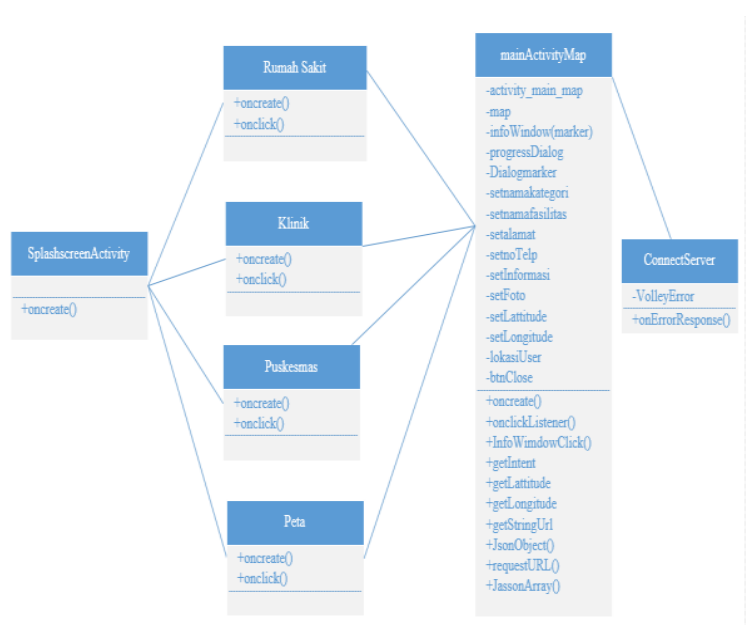

Gambar 5. Class Diagram Aplikasi Faskes Manado

\section{Tahap Pembentukan Prototype}

Pada tahap ini penulis akan melakukan penulisan kode kedalam program sesuai dengan tahap perancangan yang telah dibuat dan tools yang akan di tentukan sebelumnya. Kemudian akan dilakukan pengujian sistem untuk mengetahui apakah system tersebut masih di temukan kesalahan sehinggah harus diperbaiki atau tidak.

\section{Implementasi Basis Data untuk Server}

Data yang telah diperoleh diolah dengan menggunakan MySQL dengan menggunakan aplikasi pendukung XAMPP.

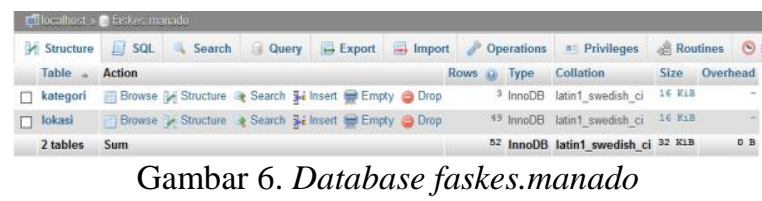

Pada Gambar 6. merupakan table database yang telah dibuat dengan nama database faskes.manado. Didalam database tersebut terdapat dua table yaitu table kategori dan table lokasi.

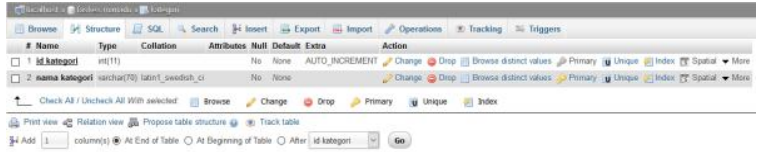

Gambar 7. Struktur table kategori

Pada Gambar 7. menampilkan struktur table dari table kategori, yang terdiri dari, id_kategori dan nama_kategori.

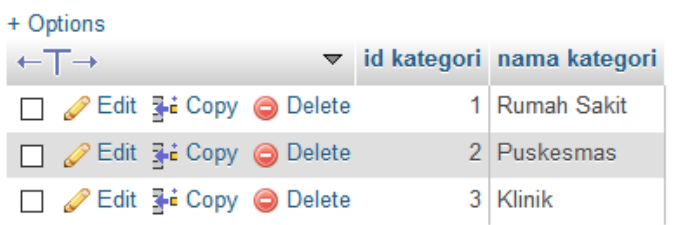

Gambar 8. Isi tabel kategori

Pada Gambar 8. diatas menampilkan database isi dari table kategori, yang terdiri dari Rumah Sakit, Puskesmas, dan Klinik.

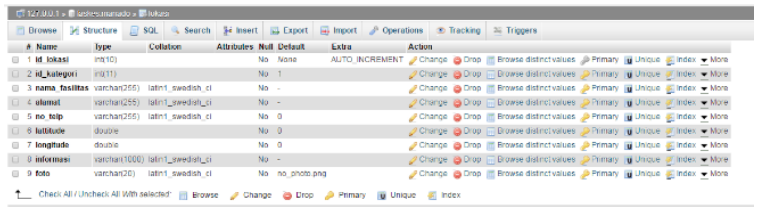

Gambar 9. Struktur tabel lokasi

Pada gambar 9. diatas menampilkan struktur table dari table lokasi yang terdiri dari id_lokasi, id_kategori, nama_fasilitas, alamat, no_telp, latitude, longitude, informasi dan foto.

\section{E. Tahap Penyerahan Sistem}

Pada tahap ini aplikasi yang telah melewati tahap pengujian atau yang sudah selesai, siap untuk di implementasikan di Kota Manado.

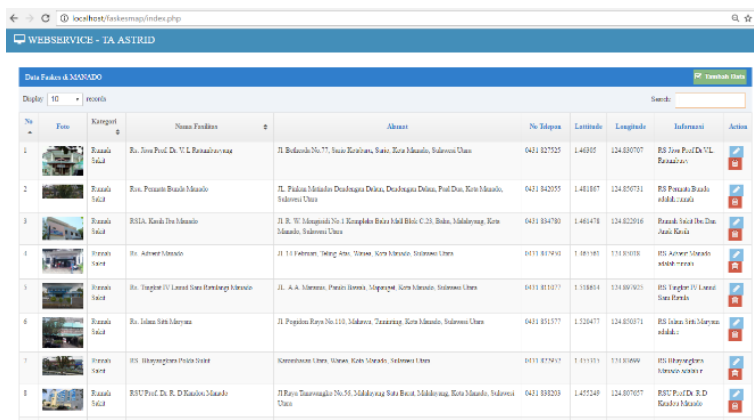

Gambar 10. Tampilan Web Service Data Lokasi Fasilitas Kesehatan 
Pada gambar 10. Dapat kita lihat semua fasilitas kesehatan di kota manado di tampilkan dalam bentuk table yang lebih terstruktur.

Setelah melalui proses pembuatan aplikasi berikut ini adalah proses uji coba dari Aplikasi yang sudah dibuat.

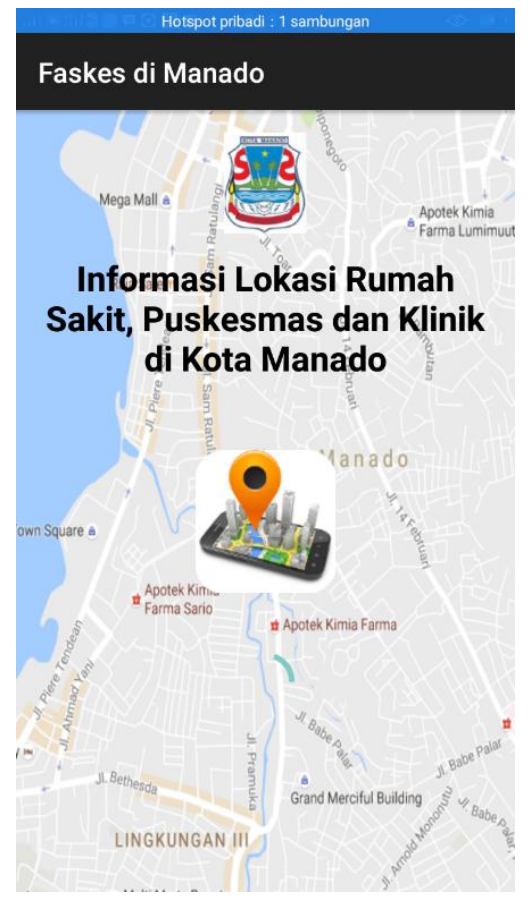

Gambar 11. Tampilan splash screen Aplikasi

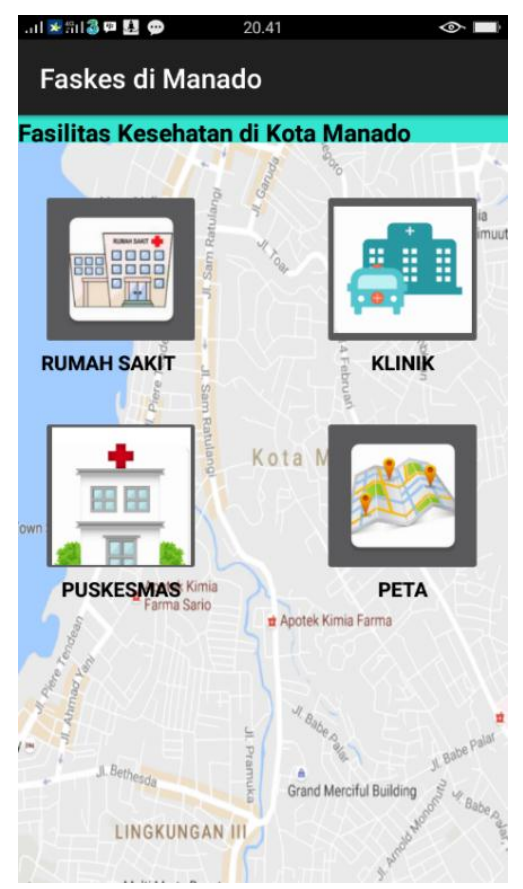

Gambar 12. Tampilan menu kategori

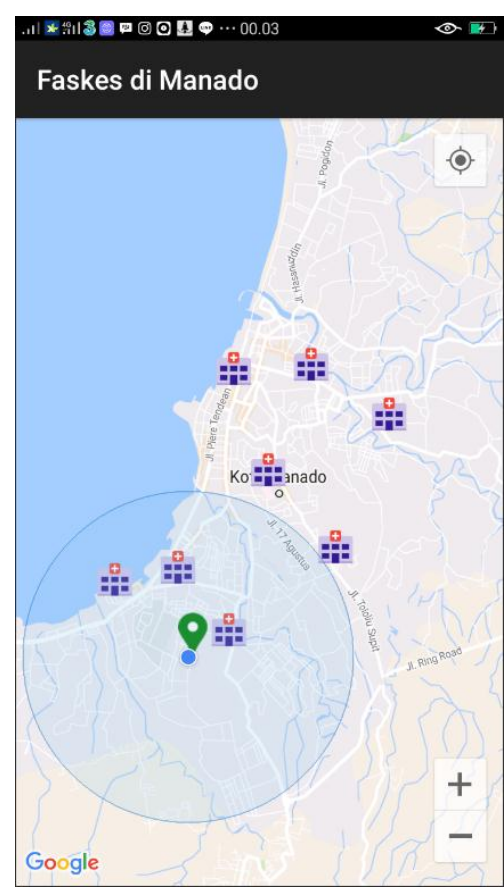

Gambar 13. Tampilan melihat peta Kategori Rumah Sakit

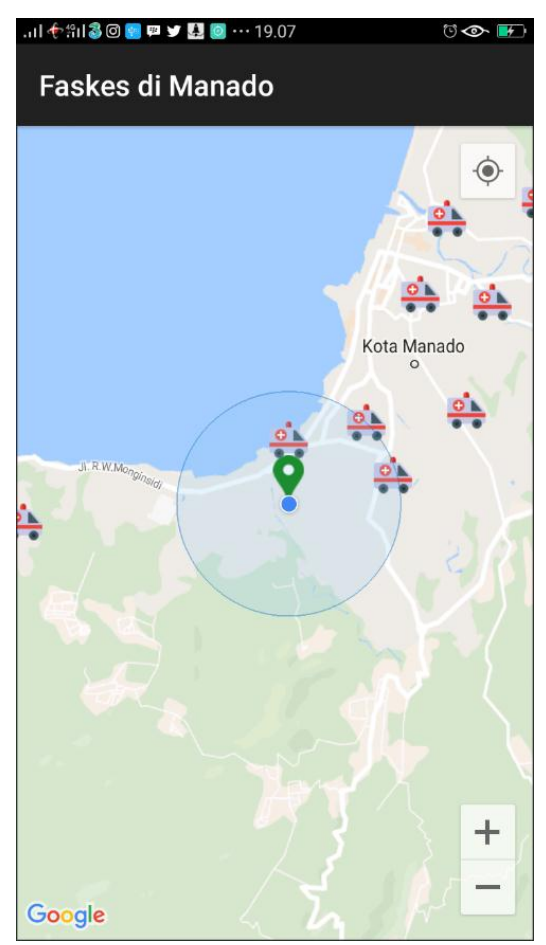

Gambar 14 Tampilan melihat peta Kategori Puskesmas 


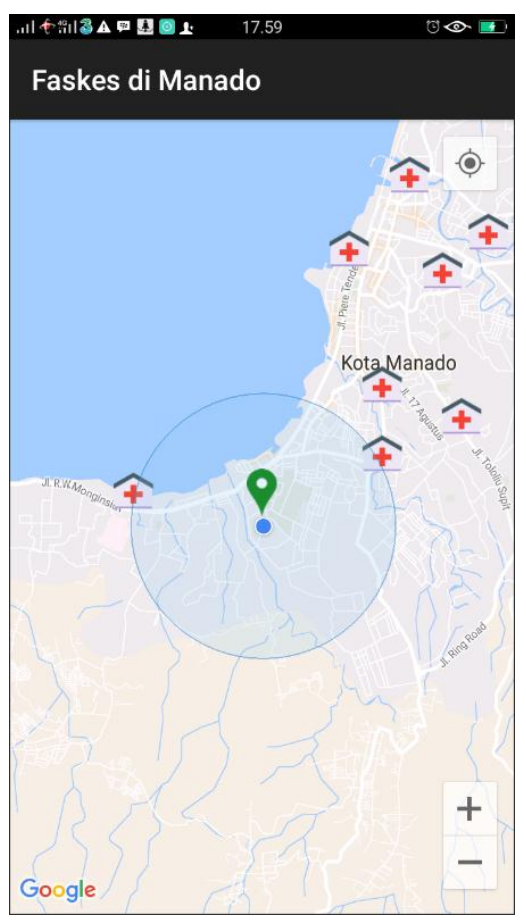

Gambar 15. Tampilan melihat peta Kategori Klinik

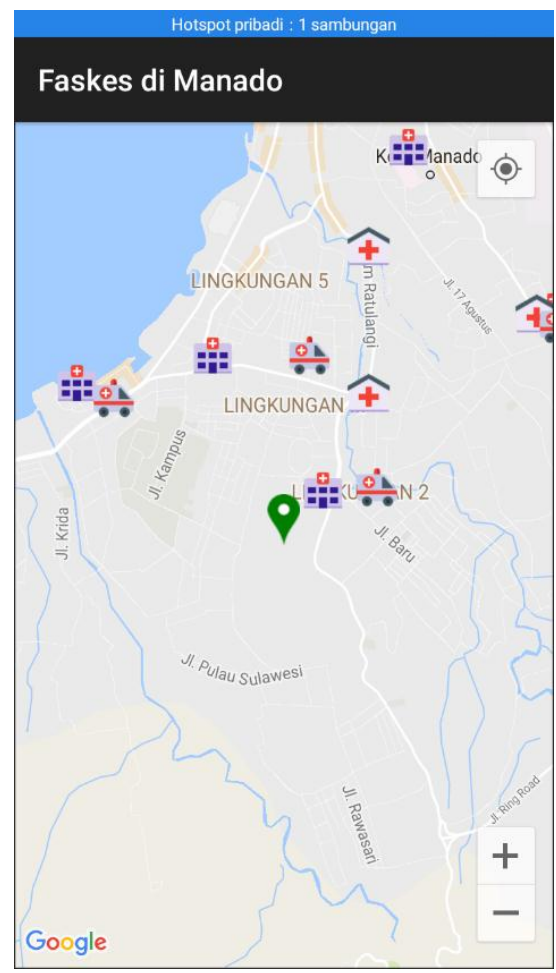

Gambar 16. Tampilan melihat peta Seтиa Kategori

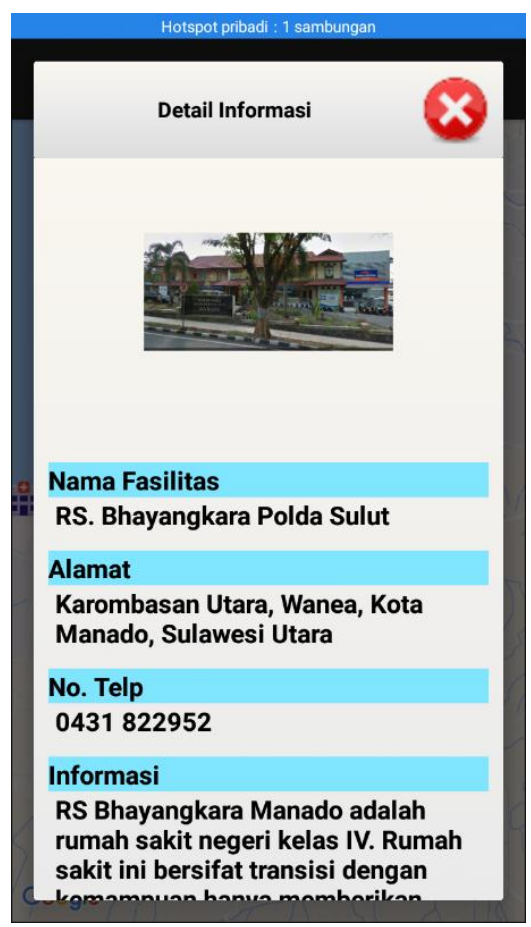

Gambar 17. Tampilan melihat detail Informasi

\section{F. Pembahasan}

Aplikasi yang dibangun merupakan aplikasi mobile berbasis client server. Pembuatan Aplikasi pencarian Rumah Sakit, Puskesmas dan Klinik terdekat ini bertujuan untuk membantu masyarakat Manado dan juga masyarakat yang datang dari luar Kota Manado mengetahui lokasi Rumah Sakit, Puskesmas dan Klinik yang ada di Kota Manado. Sistem yang digunakan pada aplikasi Informasi Pencarian Lokasi Rumah Sakit, Puskesmas dan Klinik ini dititik beratkan pada pengambilan koordinat bumi pada perangkat mobile. Dalam pengambilan koordinat system memanfaatkan GPS. Kemudian untuk mendapatkan peta dan rute, sistem menggunakan Google Map APIs dengan memberikan parameter koordinat bumi. Setelah mengirim parameter tersebut ke GoogleMaps, maka GoogleMaps Server akan membalas berupa peta statik. Dalam pencarian Rute, sistem mengirimkan dua koordinat bumi sebagai alamat awal dan alamat tujuan, kemudian GoogleMaps akan membalas berupa data rute yang akan di tampilkan pada pengguna. Dalam pencarian lokasi Rumah Sakit, Puskesmas dan Klinik di Kota Manado, sistem terhubung ke server database dengan memasukkan titik koordinat latitude dan longitude dari semua lokasi. Setelah itu server akan membalas berupa data lokasi-lokasi Rumah Sakit, Puskesmas dan Klinik 
yang selanjutnya akan diparsing oleh sistem dan ditampilkan pada pengguna.

Kebutuhan data pada Aplikasi Pencarian Fasilitas Kesehatan di Kota Manado ini meliputi, data Rumah Sakit, Puskesmas dan Klinik ini merupakan data awal yang harus ada dalam sistem. Data Fasilitas Kesehatan ini meliputi nama, alamat, no telp, foto, latitude, longitude dan informasi dari suatu fasilitas kesehatan. Data inilah yang akan menjadi acuan dalam melakukan pencarian lokasi Rumah Sakit, puskesmas dan Klinik Terdekat. Selanjutnya adalah posisi Pengguna, data posisi pengguna didapat dari sinyal GPS yang diterima oleh GPS receiver pada mobile device kemudian akan ditampilkan pada saat pengguna mengakses aplikasi ini dan menajadi Informasi lokasi berdasarkan posisi pengguna. Data posisi pengguna ini bersifat dinamis selalu berubah sesuai dengan lokasi akses pengguna terhadap sistem.

Untuk mengetahui apakah sistem bisa memberikan solusi terhadap permasalahan yang ada maka di lakukan evaluasi terhadap aplikasi yang sudah dibangun dengan pengujian waktu akses, yaitu pengujian waktu yang dibutuhkan untuk mengambil content aplikasi baik itu dari server google Maps atau server Rute.

Berikut ini adalah table pengujian waktu menggunakan koneksi Android Internet Service melalui provider 3(tri 4G):

Tabel 1. Waktu mengakses Aplikasi

\begin{tabular}{|l|l|}
\hline \multicolumn{1}{|c|}{ Nama Akses } & \multicolumn{1}{|c|}{$\begin{array}{c}\text { Waktu Akses } \\
\text { (Detik) }\end{array}$} \\
\hline $\begin{array}{l}\text { Loading saat masuk } \\
\text { Halaman Menu. }\end{array}$ & 3 detik \\
\hline $\begin{array}{l}\text { Loading pengambilan } \\
\text { data lokasi Rumah } \\
\text { Sakit, Puskesmas dan } \\
\text { Klinik terdekat. }\end{array}$ & \\
\hline $\begin{array}{l}\text { Loading Map detik } \\
\text { menampilkan jarak } \\
\text { dan rute. }\end{array}$ & \\
\hline
\end{tabular}

Dari hasil pengujian aplikasi diatas dapat disimpulkan bahwa system bebas kesalahan sintaks dan secara fungsional mengeluarkan hasil yang sesuai dengan yang diharapkan sehingga bisa membantu pengguna dalam mengakses aplikasi ini. Namun tidak menutup kemungkinan dapat terjadi kesalahan suatu saat dalam menggunakan aplikasi. Waktu akses relatif tergantung pada jaringan provider yang digunakan oleh user. Khusus untuk pengambilan koordinat melalui GPS, apabila pengguna berada didalam rumah/ bangunan, waktu akses relatif lama, dan untuk mendapatkan posisi user aplikasi harus diload ke dua kali agar posisi user sesuai. Dalam menjalankan aplikasi ini pengguna juga disarankan untuk memakai jaringan provider yang lebih luas jangkauannya, agar dalam mengakses aplikasi ini pengguna tidak mendapatkan kesulitan dalam menemukan lokasi-lokasi fasilitas kesehatan yang ada di Kota Manado.

\section{KESIMPULAN}

\section{A. Kesimpulan}

Berdasarkan hasil pengujian sistem yang telah dilakukan, aplikasi pencarian lokasi Rumah Sakit, Puskesmas dan Klinik memiliki karakteristikkarakteristik sebagai berikut:

1. Aplikasi hanya dapat dijalankan jika tersedia akses paket data dari provider yang digunakan oleh User.

2. Kecepatan Internet mempengaruhi dalam penggunaan aplikasi ini.

3. Sinyal GPS mempengaruhi dalam penggunaan aplikasi ini.

\section{B. Saran}

Untuk pengembangan kedepannya yang lebih baik untuk Aplikasi Faskes Manado ini ada beberapa saran yang dapat digunakan yaitu:

1. User diberikan fasilitas untuk menambahkan lokasi user yang diinginkannya melalui perangkat Android.

2. Menambahkan fasilitas untuk memberikan rating pada lokasi Rumah Sakit, Puskesmas dan Klinik.

3. Membuat akses peta dengan peta offline.

\section{DAFTAR PUSTAKA}

[1] Ardiansyah.2011. Mengenal LBS. http://blog.uad.ac.id/ardi/2011/04/04/menge nal-location-based-service-lbs. Informatika. Bandung. 
[2] Booch G. 2005. The Unifield Modeling Language User Guide. Salemba Empat. Jakarta.

[3] Chrisman. 1997. Menganalisis dan Menyebarkan Informasi - Informasi Mengenai Daerah - Daerah Di Permukaan Bumi. Informatika. Bandung.

[4] Christian, Nora E., Yaulie DY Rindengan, and Pinrolinvic DK Manembu. 2016. Rancang Bangun Aplikasi Fasilitas Umum Berbasis Web Services. JURNAL TEKNIK INFORMATIKA UNIVERSITAS SAM RATULANGI 8.1.2016.

[5] Ciu Bun Seng. 2011. Android. Jakarta : Jasakom.

[6] Kasman, Darma Akhmad. 2013. Kolaborasi Dahsyat ANDROID dengan PHP dan MYSQL .Yogyakarta : Lokomedia.

[7] Prasetyo, Rizky Adithya. 2013. Aplikasi Mobile "Jogja Helper" Berbasis Android OS. Yogyakarta : Amikom Yogyakarta.

[8] Riyanto, Andi. 2010. Membuat Sendiri Aplikasi GIS. Andi Publishing. Yogyakarta.

[9] Safaat, Nazruddin. 2014. Pemrograman Aplikasi Mobile Semartphone dan Tablet PC Berbasis Android. Bandung : Informatika.

[10] Susanto, Raymond. 2014. Google Maps [online].Available:https://id.wikipedia.org/w iki/Google_Maps.

[11] Simarmata, Janner. 2006. Basis Data. Andi. Yogyakarta

[12] S Pressman, Roger. 2012. Rekayasa Perangkat Lunak Buku 2. Andi. Yogyakarta

[13] S Pressman, Roger. 2010. Software Engineering : A Practitioner's Approach, 7th ed. Mc Grow Hill.

[14] Peranginangin, Kasiman. 2006. Aplikasi WEB dengan PHP dan MySQL. Yogyakarta : Andi Offset.

[15] http://www.manadokota.go.id (2016).

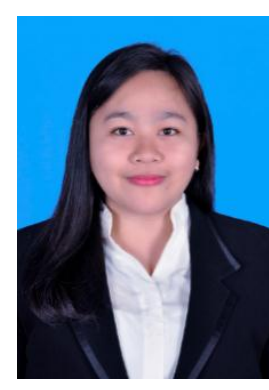

Sekilas dari penulis dengan nama lengkap Astrid Asisia Ayun Makiolor, lahir di Kota Tondano, Kabupaten Minahasa, Provinsi Sulawesi Utara. Penulis merupakan anak ke-4 dari 4 bersaudara. Dengan latar belakang pendidikan Sekolah Dasar GMIM Eben Haezer Wulauan Kota Tondano, setelah lulus melanjutkan ke Sekolah Menengah Pertama Katolik Stella Maris Tomohon. Kemudian melanjutkan ke Sekolah Menengah Atas Negeri 1 Tondano dan dinyatakan lulus pada tahun 2011. Setelah lulus melanjutkan ke Perguruan Tinggi di Universitas Sam Ratulangi Manado dengan mengambil Jurusan Elektro Program Studi Teknik Informatika. Pada tahun 2015 bulan Juli, penulis membuat skripsi demi memenuhi syarat Sarjana (S1) dengan penelitian berjudul Rancang Bangun Pencarian Rumah Sakit, Puskesmas dan Dokter Praktek Terdekat di Wilayah Manado Berbasis Android yang dibimbing oleh dua dosen pembimbing yaitu Alicia A. E, Sinsuw, ST., MT dan Xaverius B.N. Najoan, ST., MT sehinggah pada tanggal 10 Mei 2017 penulis resmi lulus di Teknik Informatika Universitas Sam Ratulangi Manado dan menyandang gelar Sarjana Komputer dengan predikat Sangat Memuaskan. 